\title{
Still Christmas
}

\section{Paula Mathieu}

Paula Mathieu is a writer and teacher. She works at Boston College where she is associate professor of English and director of first-year writing. She teaches writing as social action, first-year writing, creative nonfiction writing, mindful storytelling, composition pedagogy, and rhetoric as cultural study. She wrote Tactics of Hope: The Public Turn in English Composition and co-edited three essay collections, including Circulating Communities: The Tactics and Strategies of Community Publishing (with Tiffany Rousculp and Steve Parks). With Diana George, she writes about the rhetorical powers of dissident press. She also writes about intersections between writing and contemplative practice.

I

n kindergarten, my classmates filled my head with stories of Christmas Eve, Santa, reindeer, and waking up early Christmas morning to tear open gifts. I anticipated the holiday with explosive excitement.

By Chritmas Eve, my family's house in suburban Chicago looked ready, its Christmas tree decorated with colored lights and ornaments. But the day came and went like any other. My parents and some of my seven older siblings sat together in our darkened family room, waiting to attend midnight Mass, watching It's a Wonderful Life. Perhaps the movie's message of a man overwhelmed by too many kids and business pressures who learns his life is indeed wonderful resonated with my parents. Or maybe they watched it because it aired annually on PBS. I dozed on the couch, waiting in vain for Christmas to begin.

By 5 a.m. Christmas morning, I crept from the bedroom I shared with two sisters and raced downstairs to find no gifts waiting under the tree. No one was awake. A neatly tacked white sheet sealed the entrance to our living room so tightly I couldn't peak inside.

By 7 a.m., my parents were up, sleepy in their robes and slippers, brewing coffee. I was confused that my parents seemed neither excited nor happy. Had I gotten the day wrong? It took all my nerve, but I whispered to my mother, "When's Christmas?"

She took a slow breath and replied, "Once all your siblings," whose ages at the time ranged from early 20 s to preteen, "are awake and have eaten breakfast, then we take down the sheet." Any gifts were in the living room, with that sheet blocking any view into the room. I considered donning my snow boots and marching outside to peak through the window but thought better of it. The rules seemed so unfair. But I didn't know the actual, unspoken rule: Christmas couldn't begin until all the kids were proven alive.

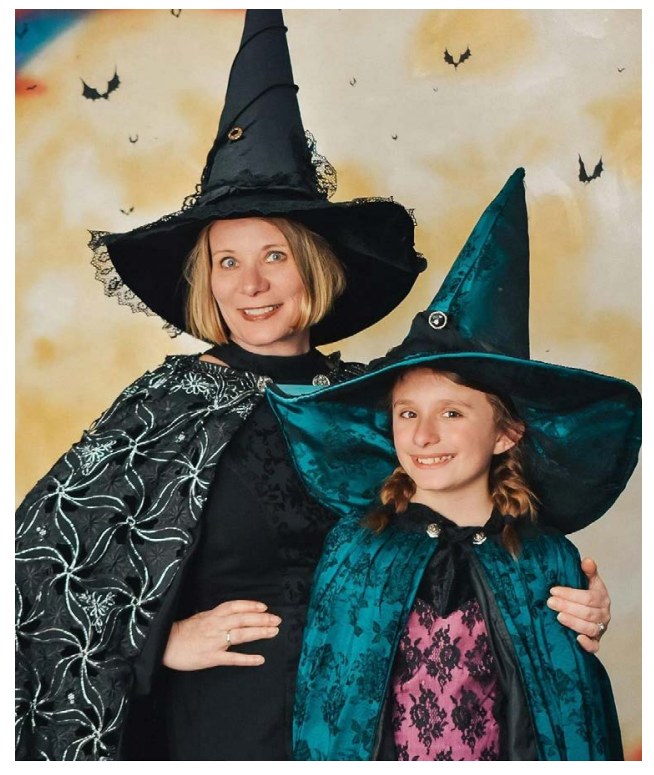

\section{Abstract \\ "Still Christmas" is a work of creative nonfiction, where the writer explores a legacy that she shares with her mother- one of secret loss and shame-while seeking to use writing as a tool to break the pattern of silence.}

\section{Keywords}

motherhood, trauma, breaking a story, SIDS, miscarriage, storytelling, restorying 
The scene looked festive-a decorated Christmas tree and a dining table set with my grandmother's china-but the mood was somber. My mother seemed especially tense. Small things-when she did not get the turkey into the oven on time and when I spilled milky cereal on the kitchen counter-caused her temper to boil. She slammed the oven door and growled to no one in particular, "Why aren't my dishcloths where they are supposed to be?" I felt guilty as I raced to wipe up the milk because I believed my clumsiness was the source of her mood. Her anger passed quickly, replaced by awkward silence. I tiptoed around, trying not to further upset the morning of waiting.

Around midday, once my siblings had dragged themselves through breakfast, my father took down the sheet, and we filed into the room containing wrapped presents. There was no mad dash or tearing. At my mother's request, we opened gifts one at a time. My siblings gave short responses like "Gee thanks." My first box held a burgundy winter hat. I so longed for the joy of Christmas, I forced a squeal of delight and insisted on wearing that hat all day. I knew it would be a good 30 minutes before I would open another gift, but I didn't object because I didn't want to sour my mother's delicate mood.

Rather than wrapped gifts or dinner on china plates, I wanted to sit in my parents' laps. I wanted laughter. I wanted to understand why the mood in our house felt so heavy. I wanted real conversation. I didn't know it, but I wanted the story of my oldest sister.

I discovered that I was the youngest of nine children, not eight, at my father's funeral, on a humid August afternoon when I was 15 years old. My father had died suddenly and unexpectedly a week earlier, a heart attack in Amsterdam's airport, while on a long-planned trip to Europe with my mother. Instead of starting the first week of my junior year of high school, I rode silently in a limousine with my siblings and my mother, who had barely said a word since returning home alone from Amsterdam. When the funeral procession arrived at Chicago's Holy Sepulcher Cemetery, I followed those ahead of me, watching my step as my uncomfortable heels sank into the soft grass. When I looked up, I saw for the first time a large family headstone bearing my last name. As pallbearers placed my father's casket on a scaffold that would lower it into the ground, I began reading the inscriptions indicating the births and deaths of my grandparents, uncle, and aunt.

Below those names, I encountered the short, and until now, only written version of my oldest sister's life story: Marcia Mathieu: Nov 15, 1954 to Dec 24, 1954.
Keeping myself upright in the August heat at my father's graveside while just a teenager took all my strength and will, so figuring out who Marcia was and what she meant to me would be work for another day.

I never mustered the courage to ask my mother about my oldest sister who died on a Christmas Eve ages before I was born. I couldn't imagine asking a grief-stricken 53-year-old widow with eight children to talk about a loss she had kept secret for three decades. Even if I had found the courage, I wouldn't have known how to broach this issue with her. Whenever I talked with my mother about anything, like spending the night at a friend's house, I paced nervously before asking, rehearsing with knots in my stomach. "Mom, can I spend the night at Amy's house tomorrow night?" The answer was usually yes, so it wasn't conflict I feared, just the encounter itself. Why I felt so nervous was never clear to me, so I attributed it to my own awkwardness. If the issue was in any way significant, I lost my nerve before words were ever uttered. That tension explains why Amy's mother, not my own, bought me my first training bra, why I learned about menstruation from a Judy Blume book, and why my mother and I never talked about my father after his sudden death.

$* * *$

I suspect the lack of stories and meaningful words in my home indirectly propelled me to become a teacher of writing, someone who encourages others to share their words and stories with the world. But until now, I have shared precious few of my own stories and have not explored in writing why and how I was shaped by a household filled with silences and unspoken pain.

Any story I write about my family will always remain flawed, limited to my perspective, clouded by memory. I am doomed to get it wrong. What's more, the act of writing about this topic feels like a transgression, the breaking of a fundamental but unstated family rule: keep our painful stories silent.

Silence, however, has exacted a high cost, for me at least and I suspect for my mother and others as well. In trying to let some untold parts of my family's story escape onto this page, I hope to break a silence brought on by shame and fear and not to perpetuate that shame in my own family. Perhaps someone reading might recognize something about their own family, their experiences, or their unspoken rules. Perhaps they will find a part of themselves in these stories and feel less alone. ${ }^{1}$

***

In December 1954, snow blanketed the Chicago area, which was a welcomed relief from a summer that had brought record heat. My

1 This line invokes and acknowledges the fine work of Amy Robillard, especially her book We Find Ourselves in Other People's Stories: On Narrative Collapse and a Lifetime Search for Story (New York: Routledge, 2018). Robillard's essayistic blending of sometimes-traumatic stories from her life with her research about writing is beautiful, incisive, and has paved the way for me to imagine publishing a story like this for an audience of writers and writing instructors. 
oldest brothers were preschoolers, anticipating a white Christmas with my parents and their baby sister, Marcia, who had just turned a month old. Our tidy brick house in Harvey, Illinois, was filled with smells of baking apple pie and a live Christmas tree. Wrapped Christmas gifts hid out of sight.

I don't know who found Marcia's lifeless body in her crib on Christmas Eve. Did one of my brothers, excitedly, try to wake his baby sister? Did my father come home from work early to nuzzle his baby girl? Or, most likely, was my mom so busy with both boys and Christmas preparations that when her baby girl didn't cry, didn't distract her just this once, she enjoyed, relished even, a sweet stretch of time pulled in one fewer direction? Did she wait long past the time Marcia should have awakened before she checked on her? Would those stolen, relished moments forever remain my mother's deepest regret?

I don't know. This Christmas unfolded a decade and a half before I was born, and my brothers remember little from that time. They were practically babies themselves. The oldest, only four at the time, recalls confusion, firemen running in the house: "Why were there firemen when there was no fire?"

He shared this information with me a few years ago when I mustered the courage to email him to ask him about our sister for the first time. He replied within hours. "Mom was terribly upset," he wrote. "I was telling her not to cry, but I didn't know what was going on."

Other than exchanging emails, I have never talked with any of my siblings about my oldest sister. In my house growing up, Marcia's name or any fact of her brief life was never mentioned or even alluded to.

I have a daughter. In the sleep-deprived haze that comprised the first months of her life, I alternated between two fears: of her not sleeping, which was most of the time; and of her not waking when she managed to fall asleep. A baby is so fragile, so tangentially part of this world, as much spirit as physical presence that each breath feels like a miracle. How can one keep expecting miracle after miracle?

As a new mother, I feared Sudden Infant Death Syndrome, a much-debated but sobering reality that some otherwise healthy babies die unexpectedly without clear reason. We now know the risk is greater in the winter, when babies are fewer than four months old, when blankets are in the crib, and when babies don't sleep on their backs.

In 1954, my mother, just 25 years old, knew none of these things. No one did. Doctors then told the story that sudden, unexpected deaths of babies, like my sister, were accidental suffocations: sad but tragic parental mistakes. I picture my mother sitting alone, a cigarette in her trembling hand, while everyone moved quickly around her, doing what needed to be done. They didn't blame her, at least not directly, but everyone knew who should have protected her infant daughter. My mother, most of all, would have known.

The firemen would have tried in vain to revive the baby. The police would have been called to rule out criminal behavior. The officer would have been sympathetic but businesslike, kicking snow off his boots, talking in hushed tones with my father, who would have rushed the two miles home from his auto dealership after my mother's frantic call.

Practical things would have happened. An ambulance would have taken Marcia's body away. Much would have been removed from the house: wrapped Christmas presents. Baby girl clothes. Anything pink. The crib itself.

The subsequent six babies-who would be the last thing on anyone's mind that day-would sleep elsewhere. No one should sleep in a dead baby's crib. My father would remove anything that reminded my mother of Marcia.

He would even remove the family itself, whisking them to Florida for an impromptu trip, hoping to fly away from reminders of Christmas and the sympathetic-but-accusing stares of neighbors. My mother would have landed hundreds of miles away from her baby's tiny body, in a place that must have felt too sunny, too humid, too out of synch with her grief. In paradise, she still had two young boys to tend. Boys old enough to ask painful questions- "Where is Marcia? Where is baby?"- but not old enough to understand the pain such words could cause.

***

Almost exactly a year after Marcia's birth, my mother delivered another baby girl, my oldest living sister, who turned a month old on Christmas day, one day after the anniversary of Marcia's death. How many hours must my mother have watched this baby's tiny belly rising and falling as she slept? How old did she have to turn before my mother could tell herself this one would live?

And just when my sister turned a year old, my mother had yet another newborn, another son. Over the next dozen years, my mother gave birth to and raised four more babies, including me, the youngest. She provided for us, cared for us, but she rarely engaged us physically by holding us, or emotionally through meaningful conversation.

$* * *$

My mother rebuffed any attempt to discuss Marcia. My oldest brother's email reported that he tried to talk with our mother about their shared loss months or years later, he's not sure anymore. She flatly refused, even though he shared the trauma with her as well as memories of his sister. 
When my oldest sister was a teenager, she watched Marcus Welby, MD on TV with my parents, and the plot involved an infant's sudden death. During the show, my mother began to cry and quietly raced upstairs.

"What was that about?," my sister asked my father. He took off his glasses, turned off the television, and addressed my sister: "Before you were born, we had a baby girl who died." My dad spoke in a matter-of-fact but grave tone. His willingness to talk suggests that perhaps his silence was in deference to my mother.

After she talked with my father, my sister went to my mother, alone in her bedroom. My sister knocked and carefully stepped in. "Would you like to talk about it, Mom?," she offered gently. As she moved to sit on the bed, she added, "Dad told me what happened, why you're upset. Can we talk?"

My mother's face was turned away, and she didn't turn around. "No," she said to the wall.

"It might make you feel better to talk about it," my sister said quietly, trying not to give up too easily.

"No." My mother's answer was final. My sister waited for something more, but it never came. She perched awkwardly on the bed, staring at her mother's back, rubbing it gently. She eventually left the room.

When I was in my early twenties, one of my brothers named his first daughter after Marcia, maybe as an effort to honor the sister he never knew. He spelled the name differently because even the spelling of our secret sister's name was uncertain to us. The Chicago cemetery was the only place to clarify the spelling, and my brother was living in California.

After my niece's birth until my mother's death two years later, my mother never spoke her granddaughter's name. She simply called her "the baby," even though by then my mother had five other grandchildren. When she said "baby," we all knew whom she meant. Even a slightly wrong version of Marcia's name held the power to tear the lid off my mother's tightly sealed pain.

To love and be loved by my mother was to be present together, often wordlessly. I spent hours observing her, taking her in. She was petite and classically beautiful. Despite bearing nine children, she returned to her 5-feet-tall, 110-pound frame within months of each birth. She dressed with classic, understated style. No detail was overlooked. She wore her hair blonde in a short bob, which she had washed and set weekly at the hairdresser. Her nails were always polished. Although she could tan easily, she took great care of her skin, wearing a broad hat while sunning. Each night she rolled her hair into pin curls, securing each one with bobby pins, used various creams to remove her makeup and cleanse her skin, and meticulously cleaned her teeth. Every action was deliberate.

As she readied herself for a new day, she perched at her dressing table before a large makeup mirror, wearing a taupe dressing robe and wedge-heeled slippers. I often sat on the floor watching her as she added foundation, powder, eye makeup, and lipstick, took down her hair, and then, finally, dressed. I debated with myself about which way she looked prettier: in her pin curls with no makeup and robe, or dressed, fully made up, with hair curled under the chin. I preferred her unadorned look because we saw so little else of her private side.

While I spent hours watching my mother, I did not imitate her. I was athletic and wore by brothers' hand-me-downs, as did my sisters, much to my mother's disappointment. For Catholic school, we wore plaid uniform kilts, white blouses, red cardigans, and knee socks, so wearing a dress during off hours felt like torture. I climbed trees and played softball. My sisters and I also shared our father's stockier build, so I was both taller and heavier than my mother by seventh grade. When I noticed this aloud one day, my mother remarked matter-of-factly, "You have Mathieu legs," meaning thick and white like my father's, not tan and birdlike like hers. My cheeks flushed hot as my body felt impossibly big.

Sometimes I wore a dress to please my mother or let her blow-dry my long hair, but I never managed to stay kempt. I was (and still am) clumsy and scatterbrained, so my dress bows never stayed tied, I often lost track of one sock, and my hair easily misbehaved and tangled. I returned home from school each day healthy but disheveled. My mother called me a ragamuffin, a term that stung, especially when I tried to look feminine. I longed for her approval, but aspiring to be like her never seemed an option.

\begin{abstract}
From spending time at friends' houses, I knew that my family was different, that we talked less than others, that my mother was reserved. I loved my friends' moms who peppered me with questions, and I enthusiastically answered them all. At school, I raised my hand to answer questions perhaps too often. Writing and my imagination became a safe place for me, a space to venture ideas without too much risk, to offer words without fearing a response. To avoid hazarding too much conversation, I sometimes I wrote notes to soothe squabbles with my sisters.
\end{abstract}

To explain my family to myself, my inner voice cooked up stories that tended to be highly critical of me and my actions. Our brains are powerful and compulsive tellers of stories and will try to create coherent stories, even without enough information. ${ }^{2} \mathrm{Had}$ I been born with a different constitution or brain chemistry, I might have spun heroic tales about a curious mind trapped in a land with no

2 Here I draw from Jonathan Gotschall's The Storytelling Animal: How Stories Make Us Human (New York: Houghton Mifflin, 2012). 
words, a mind on an adventure to escape to a mythical kingdom where words run free.

My voice, however, was trained by a middle-class white sensibility where one never named even obvious racial contradictions (like the local clubs that barred Jews and blacks), by Catholic schooling that taught obedience above all else, and by an introverted shyness that caused constant self-questioning. I tried desperately to be the good girl, the one who could fix our broken family by behaving better than anyone ever had, who believed diligence, good grades, and cheerfulness could heal the vague unnamed pain that pervaded our house. And when that didn't work, because of course that didn't work, I felt not good enough. If I had only been a bit smarter, a bit more godly, and a bit less, well, me, the fairytale happy ending would have come.

Sometimes an illusion of control carries a heavy cost. At least in my story, I was the feeble hero, and the world was of my making. But that meant I had failed in my quest to restore my family to happiness and to words.

Now, by writing about the silences in my family, which were fueled by trauma and shame, I aim to tell a version of my family's story with a hope that writing it can change something or someone, especially me. At the same time I fear this desire might be a re-enactment of the same hero complex I held as a child: if only I can find the right image, the most beautiful words, I can craft the story that will heal my family. I become filled with the same fear that I (and my writing) are just not up to the task.

Hoping for catharsis, I lament: if only I could write this story correctly.

When my husband and I learned I was pregnant, I was happy and scared and thrilled. It wasn't unexpected. I told myself we were no longer trying to prevent pregnancy and would see what happened. I filled my mind with positive thoughts and my body with lots of water and healthy food. Once I saw the plus symbol on a home pregnancy test, I visited my doctor. We kept the news under wraps because it was early, but I got plenty of rest, documented the growth of our little bean, and didn't think about caffeine or alcohol. Weeks passed.

When I was days shy of 12 weeks pregnant, which is usually believed to be the safe time to announce a pregnancy, I stopped in the bathroom after teaching my once-weekly creative nonfiction workshop before commuting home from the university. Blood. Not a lot, but enough to cause concern. I called my doctor, who said to rest and come to the office first thing the next morning. At night I started cramping and feared the worst. At the doctor's office, the microphone couldn't find the baby's heartbeat.

"Before we come to any conclusions, I want to send you to the ultrasound lab. Sometimes bleeding is normal, and the baby might be positioned so we can't hear the heart.

Let's assume the best for now." I appreciated my doctor's reassurance, even though it felt hollow.

By noon, the possibility of the best was ruled out. "I can detect no signs of life," the lab technician said quietly, "I'm sorry." I was told to check into the hospital because being three months along, I would need a procedure to help the no-longer-living baby find a way out. I reported to the labor and delivery unit, painfully aware of the irony.

By the time I was admitted and gowned, the cramping was intense. I was crying for my baby who wouldn't be and for the shame I already carried, sensing I had done something to cause this miscarriage. I asked to go to the bathroom before they administered anesthesia, where my body passed impossible amounts of blood. The nurse grabbed me before I teetered to the floor. Soon I was asleep.

When I awoke the nurse was holding my hand. "You're fine, physically. This is an awful day, but l'll see you back here for a happier day sometime soon. I promise."

Those were kind and soothing words. But the fact was, she couldn't promise. She didn't know. My doctor said one miscarriage was "clinically insignificant," so I should wait a few months, and if it happened again, we'd do some tests.

The next day, a Friday, as I was home recovering from the procedure, my husband handed me the phone, saying it was from work.

"Congratulations, Paula," I heard. I winced, as the words hit hard.

The voice belonged to the dean of Arts and Sciences informing me that I had been granted tenure and promoted to the rank of associate professor in the department of English. This milestone was the culmination of 15 years of postundergraduate work, three book projects, a dozen articles, six graduate and undergraduate syllabi, 11 semesters of teaching, hundreds of students taught, thousands of papers graded, millions of words of student writing read, and six months of waiting after handing in my tenure dossier.

This call should have filled me with joy and relief, but I could barely listen as I reeled from the dean's congratulatory wishes. I failed to sound pleased or grateful. I managed not to cry until we hung up, but the poor man must have wondered why I sounded like the least happy tenure recipient ever.

Back at work after the weekend, many colleagues popped their heads in my office door, sent a note, or emailed warm, well-intentioned celebratory words, to which I smiled and gritted my teeth. I wanted to feel happy. I should have been celebrating. But every 
"Congratulations" invoked my baby who would never be.

Almost no one knew about my loss. I hadn't meant to keep anything a secret; we were just following the normal "keep it quiet until after the first trimester" logic. But somehow, announcing a miscarriage when no one knew I had been pregnant when I was supposed to be celebrating a professional milestone seemed a bit too incongruous.

As much as I considered myself so different than my mother, I found myself like her: mourning a secret loss, expecting everyone around me to magically sense my grief and care for me, feeling angry when unsuspecting friends and colleagues turned out not to be mind readers.

Half a year later, I was pregnant again, but nothing felt the same. Even the plus sign on the pregnancy test was faded, like it wasn't sure it was true. With every bathroom trip, I expected to see blood. Every doctor's visit, I awaited bad news. I had neither the positivity nor the will to eat healthy foods and hydrate. I suffered debilitating headaches, and my doctor advised me to drink a cup of coffee a day. I did and loved it, withstanding questions and disapproving looks from servers and passersby. I was doing everything wrong with this pregnancy, but likely it wouldn't matter anyway.

Except that it did. Despite my ambivalence and fear, eight days before her due date, my daughter arrived, a little on the small side but a healthy, dark-haired spitfire.

Perhaps like my mother, I beheld the creature I most wanted with love and terror. I hadn't been the model expectant mother. Had I harmed her? Why hadn't I eaten more leafy green vegetables? Was my milk supply limited because I hadn't hydrated enough? I quickly learned that parenting opens new paths for unbridled self-criticism because every decision is made while exhausted and uncertain.

Less than 48 hours after my daughter's birth, I sat in a wheelchair, a nurse handed me an infant, and my husband wheeled me out of the hospital. As the security doors of the maternity ward opened to the rest of the hospital, I looked down on this tiny, fierce, and breathtakingly beautiful creature as my pulse raced through my stomach and limbs. Despite being a grown-up, a tenured college professor, and a wife, I had no idea how to be a mother. And both my husband and I were without our mothers to guide us.

\section{$* * *$}

My daughter was healthy, according to the doctors, but she cried more loudly and more intensely than any other infant I had ever encountered. She cried hours straight each night. And the two things infants were supposed to do reliably-eat and sleep-happened fitfully and infrequently.
Why did she cry so much? Lactation consultants offered advice on how to help my daughter latch, how I could make more milk, how to eliminate dairy, soy, wheat, and sugar from my diet in case her fussiness was due to allergies, how to pump when she wasn't nursing adequately, how to apply salve to my bleeding and sore nipples, how to supplement with formula. Around the clock, I spent hours hooked up to a ridiculous pumping machine extracting milk from my tender breasts, then pacing or bouncing on a large exercise ball to coax my daughter to drink the milk from a bottle.

I cried every single day. I rarely slept two hours in a row. One night, I wondered if my daughter might be possessed. If I hadn't had the luck of being on sabbatical that semester, I am sure I would have lost my job.

During one week of crying, Penny, our mixed-breed dog, curled tightly into her bed and put both paws over her ears to try to quiet the intense noise. A photo of Penny in that pose brings back all the sleep-deprived intensity of 2008.

When my daughter wasn't crying, or when she slept in my arms or on my chest, my heart ached at how beautiful she was. Her dark hair was thick and stood up everywhere. Her intense brown eyes took in everything.

I joined a new-moms group, which forced me to venture out of the house and start to explore life with a baby. As a group, we cried and shared fears, but I noticed that the other babies slept through our meetings, calmly in their moms' laps like warm potatoes or nursing without a peep, while my baby wriggled or cried or needed to be bounced. The other moms ate lunch together after our weekly meeting, while I raced home to pump. I shared with my new friends some of my challenges-they were obvious-but I didn't let on how hopeless and afraid I was.

My fear, and the stories I told myself about this fear, created deep shame: that I was failing as a mother, that I couldn't soothe my daughter. The more ashamed I felt, the more I hid these feelings from friends and family.

When my daughter turned a month old, a nurse from my insurance plan phoned. "How are your daughter and you doing?" she asked.

I burst into tears. To my own surprise, out spilled my story of how little she slept, how hard she cried, how she rarely stayed still. This nurse, whom I had never met, replied with remarkably calming words. "Sometimes, children who are passionate, full of life, and curious are not the happiest of infants," she told me. "The qualities making your life difficult right now will be the very things you love in your daughter as she gets older." She sounded so sure of herself.

"I know you're just saying that to make me feel better," I practically whispered into the phone, "but it's working. Do you really believe what you're saying?" I knew she had never laid eyes on my child. 
"Yes," she said. "I do."

I clung to those words through the subsequent months as our daughter wailed her way through several dietary changes, an acid-reflux diagnosis, medicines, prescription formula, multiple ear infections, diarrhea and dehydration due antibiotics, overnight hospitalization at 10 months due to dehydration, and a first birthday in surgery getting ear tubes.

Our longest night was spent at Children's Hospital in Boston, watching as a group of five medical technicians took 30 minutes to insert an IV into our 10-month-old, poking, failing, poking again as she wailed and wailed. We stood helplessly as our baby looked pleadingly into our eyes and screamed.

Once the IV was finally inserted into her ankle and taped so she couldn't pull it out, we spent many hours alone behind our curtain in a shared room. I climbed into the crib to soothe our baby as she got needed fluids. We saw no doctors or nurses, although we overheard questions asked of the mother in the other curtained bed in our room: "Does your son have vision in either eye? When was his trachea tube inserted most recently?"

Our irritation of not being checked on melted into the humbling realization that our daughter was probably the least sick patient in the hospital. As scary as the night was, the doctors assured us our girl would soon outgrow her challenges.

My baby lived. She grew into the furiously happy toddler and adventurous child the nurse had promised. My sister, Marcia, lived 39 days and died, without warning.

Before I became a mother, 39 days seemed like a short time, a blink of an eye. I now appreciate how much mothering would have been poured into Marcia's 39 days. Eating once every three hours, Marcia would have been fed 312 bottles, almost exclusively by my mother, accounting for about 156 hours spent holding, feeding, and gazing at this tiny creature. My mother didn't nurse, like most US white middle-class women in the 1950s, and all those bottles would have been washed by hand, as dishwashers were found in only $4 \%$ of US homes during the 1950 s. A newborn soils six to 10 diapers per day, which means my mother changed Marcia's cloth diaper fastened with safety pins somewhere between two and four hundred times. And of course, Marcia's diapers would have been in addition to the hundreds of diapers my mother would have changed during that same time for my two-year-old brother.

I know how exhausted I was when my daughter was 39 days old. It was just shy of the Fourth of July holiday, and we were invited to a party. Part of me dreaded the idea of showering, dressing, pumping extra milk, and packing nearly a suitcase to leave the house. Another part of me rallied, excited to share my beautiful baby with others. Motherhood taught me that exasperation and fear reside simultaneously with exorbitant feelings of love and joy. I hated that I wasn't sleeping and that my baby rarely stopped crying, but I wanted nothing more than to hold her, stare into her face, and breathe her in.

Knowing what I do now, I can't fathom the horror of walking into my baby's room and finding her not breathing, not revivable. After so many moments but not nearly enough. Did time stand still for my mother? Or was it a blur? Was she able to call who needed to be called and function long enough for others to arrive? She must have, as my brothers would have been too young, and it was long before 911 existed. How did she keep living in that moment and every subsequent moment?

When Marcia died in 1954, the medical community ruled her death an accidental suffocation. ${ }^{3}$ Even though a handful of pathologists were noticing babies who died suddenly without signs of suffocation and began publishing articles as early as 1947, it wouldn't be until 1962 that parents who had lost babies started coming together, supporting each other, and questioning the medical findings to assert, in ways my mother never could, that they hadn't suffocated their babies.

Parents named Jed and Louise Row, Fred and Mary Dore, and Sylvia and Saul Goldberg were some of the first to insist sudden infant deaths should be researched. They founded parent-support groups, lobbied the NIH and Congress, and helped start pathology-research projects. A decade of mounting organization and pressure by parents convinced Congress to pass the Sudden Infant Death Syndrome Act of 1974, which allowed SIDS to be recognized, named, and funded for research.

I wonder if my mother ever caught mention of this legislation in newspapers in 1974. Probably not. I doubt debates at the $\mathrm{NEH}$ or medical legislation garnered front-page news. Even if she did, my mother likely always believed that Marcia's death was her fault.

Becoming a mother of one helped me glipse the courage it took my mother to parent after such a devastating loss. She showed up for her family, even if she white-knuckled her way through it. For my mother, and maybe to some extent all mothers, the vein of love cannot be disentangled from the fear of loss. Maybe I didn't get the closeness or conversation I wanted or even needed from my mother. But maybe, l'm coming to believe, her silence was not a choice but rather something imposed by the shame she carried.

3 To learn about the history of SIDS, I consulted Michael P. Johnson and Karl Hufbauer's "Sudden Infant Death Syndrome as a Medical Research Problem since 1945" (Social Problems, Oct. 1982, Vol. 30, No. 1, Thematic Issue on Health and Illness, pp. 65-81). 
My mother loved in small, tacit ways. When I was small, she rubbed her nose to mine as she tucked me in to say good night. She bathed and shampooed me every Sunday night, carefully combing through and drying my long hair before I paraded through our living room, clean and pajamaed for my father and siblings, who would briefly look up from the television to notice me.

When I was seven, my mother held me in her lap after Patches, the stray dog my sister brought home from college, took a bite out of my cheek, requiring nine stitches to close the gash. While that should be a scary memory, I remember it fondly because I had the rare good fortune to sit for an extended time in my mother's lap as she pressed a cloth to my face while she and my father calmly discussed the wound and who should take me to the doctor. That hour of physical closeness remains so vivid to me I have neither memory of the pain nor fear of dogs.

When as an adult I rented my first apartment, my mother mailed me a greeting card with a picture of happy blonde child on the cover. She wrote these words inside: "This picture reminds me of you as a little girl. Love, Mom."

$* * *$

If my mother had been alive when I became a mother, I wonder if a previously unbroachable path of conversation might have opened up for us, a way for us to dip into issues that forever remained unspoken.

I like to imagine my mother flying to Massachusetts for my daughter's first Christmas, when our small house was crammed with baby necessities but lacked even a single Christmas decoration. I was frantic and tearful from sleep deprivation and anxiety. I imagine my mother helping me bathe and change my baby with a skill only 18 years of parenting newborns could bring. She would have seemed contained, collected, as she did in most moments of her life. She might have said, "All babies get fussy, nothing to be worried about." And maybe she would have meant it. Or maybe she would have been silently anxious. The truth is, I can't imagine what she would have been thinking or feeling inside.

My mother was a centripetal force, powerfully, silently swirling inward to keep her thoughts, energy, and emotions contained, while to the outside world she presented an image of grace and calm. In some ways, I became her opposite: a centrifugal force that scatters belongings, ideas, words, and emotions about me, sometimes sending them out into the world. In other ways, I internalize my mother's reserve, withholding words, fearing judgment, and suppressing my feelings.

I picture us all spending Christmas Eve together, a day that would have likely resonated painfully for her, even decades after Marcia's death. Even so, she would have managed to coax her granddaughter to sleep after much pacing and bouncing.

I imagine that in those precious few hours of stillness, I find the courage to ask my mother about her life. "Being the mother of a newborn is really tough," I would want to tell her. "How did you manage it so many times?"

I have no idea what, if anything, she might have replied or where the conversation might have wandered. I'm not sure I could have asked more questions or ever voiced Marcia's name. I don't know how much she could have opened up to me about her experiences as a mother. As many times as I have tried, my imagination cannot conjure the details of such a conversation. I can't find the words.

But writing this essay has helped reduce my fear of telling this story incorrectly because getting it right isn't what matters most. What matters is the essaying, the trying: crafting a story as carefully as I can to break the silences that preceded it and the shame that fueled it. Breaking the old story is the new story. I'm guided by Rebecca Solnit's words:

Stories save your life. And stories are your life. We are our stories; stories that can be both prison and the crowbar to break open the door of that prison. We make stories to save ourselves or to trap ourselves or others-stories that lift us up or smash us against the stone wall of our own limits and fears. Liberation is always in part a storytelling process: breaking stories, breaking silences, making new stories. ${ }^{4}$

I write this story for Marcia, whose life was never worded into story. I write for my mother, who likely believed that, by action or inaction, she caused her first daughter to die and silently carried that shame throughout her life. I write for the little girl who believed if she had just been a better daughter, her house would have been happier and more filled with words. I write to shine light on shame, for it thrives in silence and shadow. I write for mothers who can feel like we always fail no matter what choices we make. I write for other writers and teachers of writing, in hopes my story-breaking will engender yours. I write for my students, who bravely share their stories with me, and I want to return the favor. I write for anyone who might find themselves in any of these stories. I write to restory my life, and in doing so I reach toward my mother, even if just in my imagination, to craft a connection we never managed to forge together.

\section{Acknowledgments}

This work of creative nonfiction is part of a larger project in which I explore traumas, secrets, and the myriad ways that the unspoken

4 Solnit, Rebecca, "Silence and Powerlessness Go Hand in Hand," The Guardian, March 8, 2017. My essay is also informed by Solnit's "Break the Story" from Call Them By Their True Names (San Francisco: Haymarket, 2018). An earlier version is available online. 
defined my early life, growing up the youngest of nine children in a Catholic family in suburban Chicago. Due to my family's tendency never to share private information or painful truths, writing this project has felt challenging and risky.

I'm deeply indebted to close friends who have encouraged me to keep on writing and not to listen to the voices in my head urging me to stop: Jessica Restaino, one of my first and most encouraging readers; Veronica House, for your unwavering love and support; Carrie Stead, for your level head and sharp eye; Sarah Ehrich, for conversations about writing scary things. Amy Robillard: your published words gave me permission to create mine. Thank you to Melanie Yergeau, Janel Atlas, Stephanie Kerschbaum, Jane Spickett, Bonnie Rudner, Dacia Gentilella, Kristin Imre, Martha Hincks, Brian Zimmerman, Aoife Sullivan, Stephanie Briggs, Alex Tsouvalas, and Delia Tsouvalas. My siblings, thank you, for tolerating my questions and my stories about our family, which likely differ from yours. Thank you also to Thomas Daley, in whose workshops I drafted much of this material, and to the workshop participants who read patiently and with care. To the anonymous reviewers of Writers: Craft and Context: I am indebted to you for your encouragement and the specific suggestions that helped me make useful revisions. And to the editors of this journal: thank you deeply for your generosity and encouragement throughout this process. 